\title{
THE DISTRIBUTION AND HABITAT PREFERENCES OF THE DECLINING SPECIES OROBANCHE ARENARIA BORKH. AT THE NORTHERN LIMIT OF ITS GEOGRAPHICAL RANGE
}

\author{
RenATA PIWOWARCZyK, AloJZy PRZEMYSKi \\ Department of Botany, Institute of Biology, \\ Jan Kochanowski University in Kielce \\ Świętokrzyska 15, 25-406 Kielce, Poland \\ e-mail: renka76@wp.pl
}

(Received: March 5, 2009. Accepted: January 11, 2010)

\begin{abstract}
Three new sites of Orobanche arenaria were discovered during floristic investigations in the Wyżyna Małopolska upland in central Poland. The new localities are concentrated in the Ponidzie area (Garb Pińczowski ridge and Niecka Połaniecka basin) and form the northern limit of the geographical range of $O$. arenaria. The paper presents information on the distribution of Orobanche arenaria in Poland, the abundance at the sites and habitats occupied by the species.
\end{abstract}

KEY WORDS: Orobanchaceae, Orobanche arenaria, distribution, habitat, Wyżyna Małopolska upland, Poland.

\section{INTRODUCTION}

Orobanche arenaria Borkh., sand broomrape, belonging to the family Orobanchaceae, which contains holoparasitic plants lacking chlorophyll and growing on other vascular plants. The family Orobanchaceae comprises 15 genera with more than 220 species worldwide. Orobanche is the largest genus with about 170 species, most of which grow in the Mediterranean region (Uhlich et al. 1995). Sixteen species of the genus Orobanche, including two ephemerophytes, are known in Poland (Mądalski 1967; Zając and Zając 2001; Rutkowski 2004; Halamski 2005). Nearly all central European Orobanche species are more or less seriously endangered (Kreutz 1995).

The broad range of the species comprises central, southern and eastern Europe, from Portugal, Spain, France, northern Italy, the Caucasus, Asia Minor, Iran to Central Asia. It is rarely observed in northern Europe, in NE France, NE Germany and in western and northern Poland. Orobanche arenaria has also been reported from northern Africa, Morocco, Algeria and Tunisia. The species probably originates from deserts of southern Russia (Beck 1930; Meusel et al. 1978; Kreutz 1995; Tzvelev 1981). It belongs to the Sub-Mediterranean-Euro-West-Asiatic element (Rothmaler et al. 2002). Polish localities of the species constitute the northern limit of its range.

As the occurrence of $O$. arenaria had not been confirmed at the majority of its localities in Poland and no new sites had been reported. The species was classified as extinct (cat. Ex) in the red lists in Poland (Zarzycki and Szelag 2006), likely to be extinct in the Sudetes (Fabiszewski and Kwiatkowski 2002), extinct (Ex) in Western Pomerania and Wielkopolska (Żukowski and Jackowiak 1995), vulnerable (V) in the Kujawsko-Pomorskie Voivodeship (Rutkowski 1997) and critically endangered (CR) in the Silesian Voivodeship (Kacki et al. 2003). All species of the genus Orobanche are under protection in Poland.

\section{MORPHOLOGICAL CHARACTERISTICS AND TAXONOMIC NOTES}

Orobanche arenaria Borkhausen, Neues Mag. Bot. (Roemer) 1:6, 1794

Syn. O. laevis L., 1753; O. comosa Wallr., 1822; O. borkhausenii Andrz. ex Besser, 1832; O. abrotiva Leyss. Sec. Reut.; O. ionantha A. Kerner, 1874; O. robusta Dietr., 1855; Phelipaea arenaria (Borkh.) Walp., 1844; Ph. comosa G. Don, 1838; Ph. obtusiloba Reut. ex Boiss.; Phelipanche arenaria (Borkh.) Pomel, 1874; Ph. atlantica Pomel, 1874; Kopsia arenaria Dum., 1822; K. borkhausenii Caruel in Parl.

Orobanche arenaria, O. ramosa L. and O. purpurea Jacq. represent the section Trionychon Wallr. in Poland. A different structure of the corolla and the calyx, especially the presence of two bracteoles by the calyx, the usually blue or 
violet corolla, and carpological and karyological characteristics (Beck 1890, 1930; Gilli 1966a; Teryokhin et al. 1993; Holub 1977, 1990) distinguish the species within this section from those within section Orobanche L. (= Osproleon Wallr.), which comprises other native species. Some authors distinguish individual genera within the two sections (Soják 1972; Holub 1977, 1990; Teryokhin et al. 1993; Schneeweiss et al. 2004a, b). Lower taxa within $O$. arenaria species were described based on the density of the inflorescence and the length and colour of the corolla (Beck 1890, 1930; Gilli 1966b).

The species closest to Orobanche arenaria is $O$. purpurea, which differs from the former by the stem suffused with purple when fresh, smaller flowers, 18-25(-30) $\mathrm{mm}$ long, with anthers glabrous or very rarely hairy at top. The stem and elements of the inflorescence are more glandularpuberulent. Species of the genus Achillea are mostly host plants of O. purpurea (Beck 1930; Chater and Webb 1972; Kreutz 1995).

\section{BIOLOGY AND HABITAT CONDITIONS}

Orobanche arenaria usually blooms from the end of May to July depending on the geographical location (Kreutz 1995). The blooming optimum occurs in the second half of June and at the beginning of July in Poland.

Artemisia campestris is the most frequent host plant of Orobanche arenaria in Europe (Beck 1890, 1930; Pusch and Barthel 1992; Uhlich et al. 1995; Kreutz 1995; Holub and Zázvorka 1999; Zázvorka 2000). In Poland the species was observed as a parasite on Artemisia campestris (Schube 1903; Muller 1911; Szczęśniak 2003) or generally on species of the genus Artemisia (Mądalski 1967). Other hosts are also reported in the literature, e.g. Artemisia arenaria, A. vulgaris, A. absinthium, A. crithimifolia, A. glutinosa, A. marschalliana (Beck 1890, 1930; Novopokrovskij and Tzvelev 1958; Tzvelev 1981; Pujadas-Salva et al. 1994). The host status of the following plants is doubtful: Anthemis cotula, Stachys recta, Eryngium maritimum, Phlomis nissolia, Andropogon gryllus, Salvia pratensis (Beck 1930).

The altitudinal range of the species is up to $1850 \mathrm{~m}$ above sea level in France, up to $1410 \mathrm{~m}$ in Sweden, 500-2500 $\mathrm{m}$ in Turkey, 0-900 $\mathrm{m}$ in Italy, 5-1600 $\mathrm{m}$ in the Iberian Peninsula, 150-600 $\mathrm{m}$ in the Czech Republic (Meusel 1978; Pignatti 1982; Uhlich et al. 1995; Foley 2001; Zázvorka 2000).

Orobanche arenaria is a geophyte. It is usually reported from xerothermic grasslands, sands, steppes, grassy and rocky slopes, and coasts. The number of known localities of the species is very small and has been decreasing, e.g. 20-30 specimens were usually recorded in the Czech Republic and Slovakia (Holub and Zázvorka 1999). It prefers full light, the warmest and warm regions and microhabitats, less frequently temperate cold climatic conditions. It colonises dry, alkaline and sandy soils, poor in organic matter. It is reported from communities of the FestucoBrometea class (Zarzycki et al. 2002). However, Oberdorfer (1994) described it as a species of the Sedo-Scleranthetea class and the Festuco-Brometea class. Rothmaler et al. (2002) recognized the species in a similar way, but also added scrub communities (Prunetalia). The species has also been described from lower units of the Festuco-Brometea class (Astragalo-Stipion, Bromion, Festucion valesiacae, Festucion vaginatae, Festucion rupicolae, Cirsio-Brachypodion), from the Crataego-Prunetea class (Berberidion, Cotinion coggygriae) and Festuco-Sedetalia (Uhlich et al. 1995). Ellenberg (1979) places the species in the Sedo-Scleranthetea class. In the Czech Republic, the species was reported from Festucion valesiacae, Helianthemo cani-Festucion pallentis, Potentillo arenariae-Festucenion pallentis (of the Alysso-Festucion pallentis alliance) (Holub and Zázvorka 1999; Zázvorka 2000).

\section{THE OCCURENCE IN POLAND}

Orobanche arenaria was reported from only 12 localities, mainly from Lower Silesia and Pomerania. The distribution of the localities is presented on a cartogram map in $10 \times 10 \mathrm{~km}$ squares of the ATPOL grid (Zając 1978) (Fig. 1). They are as follows:

1. Szczecin (Muller 1911), AB83; 2. Skłudzewo (Rutkowski 1995 npbl, ATPOL; Rutkowski 2004), CC28. 3. Włocławek (Mądalski 1967), DC73; 4. surroundings of an old distillery in Lubiąż, Wołów district (Schube 1903), BE25; 5. "Winna Mountain" hill near Lubiąż (Schube 1903), BE25; 6. Brodno, Środa Śląska district (Schube 1926), BE36; 7. Gliniany near Lubiąż (Szczęśniak 2003), BE25; 8. Wrocław: Rędzin (Schube 1903), BE48; 9. a hill near Stary Dwór, Wołów district (Schube 1903), BE27; 10. Jańska Mountain (Patryja Mountain) near Piotrówek, Wrocław district (Schube 1903), BE77; 11. Bobrowniki, Nowa Sól district (Schube 1903), BD60; 12. St. Marcin mount south of Tarnów (Knapp 1872), EF77.

The majority of records go back to the beginning of the 20th century and have not been found since. A positive exception is the discovery of a new locality in a sand pit in Gliniany near Lubiąż which is the only site that has been confirmed. Three specimens were recorded in 2000, over ten in 2001 and no specimens were recorded in 2002 (Szczęśniak 2003). Four specimens were recorded both in 2007 and 2008; however, only one specimen had a normally fully-developed inflorescence in 2008, whereas the others were variously damaged as a result of frost (Szczęśniak verbal info).

\section{RESULTS}

\section{NEW LOCALITIES}

The list of localities was provided vis-à-vis the network of ATPOL cartogram units of $2.5 \times 2.5 \mathrm{~km}$ squares (Zając 1978).

Three new localities of Orobanche arenaria were found in the Wyżyna Małopolska upland (Garb Pińczowski and Niecka Połaniecka mesoregions) during floristic investigations conducted in the period from 2006 to 2008 (Figs 1 and 2). A detailed list of species recorded at the localities is given in Table 1. Species characteristic of individual phytocoenoses at the localities and their percentage share are presented in Figure 3.

Locality I. Situated in the eastern part of the Garb Pińczowski ridge between the "Grodzisko" district in Pińczów 


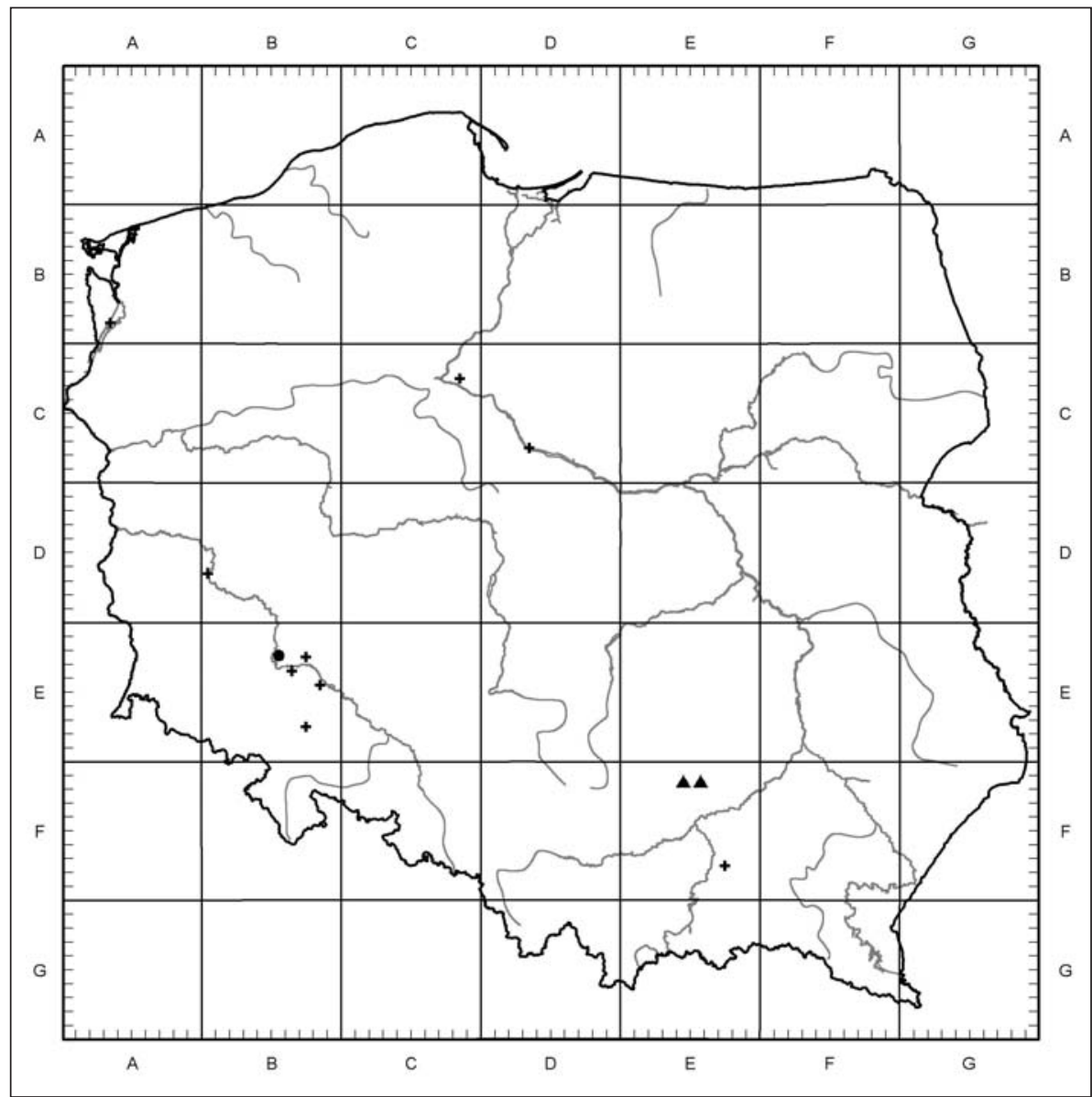

Fig. 1. Distribution of Orobanche arenaria Borkh. in Poland (in the ATPOL grid, $10 \times 10$ $\mathrm{km}) ;[\mathbf{A}]$ - new localities, [O] - current localities, +- extinct localities.

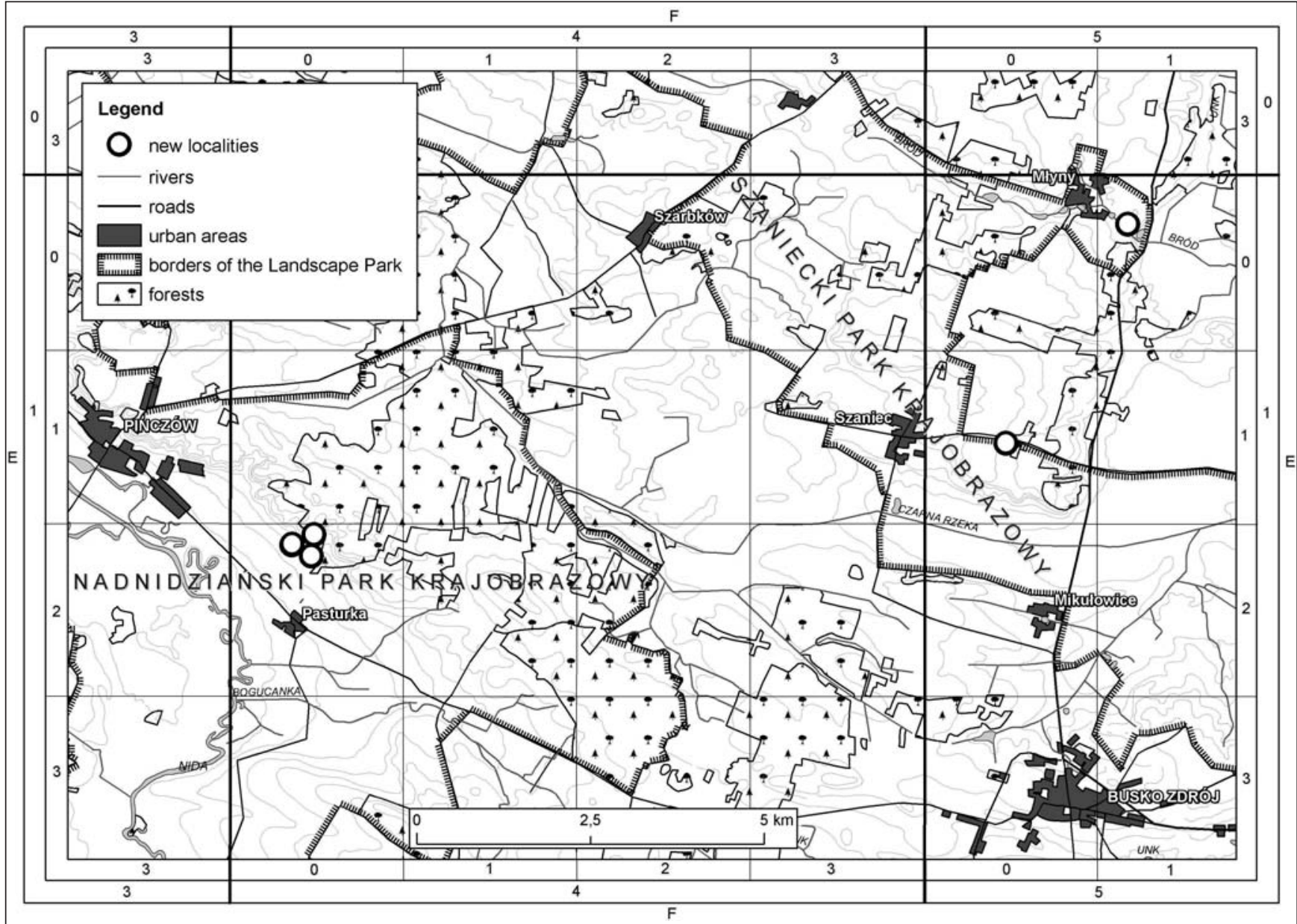

Fig. 2. New localities of Orobanche arenaria Borkh. in the Ponidzie area. 
TABLE 1. Plant communities with Orobanche arenaria Borkh.

\begin{tabular}{|c|c|c|c|c|c|c|c|c|}
\hline Number of relevé & 1 & 2 & 3 & 4 & 5 & 6 & 7 & \\
\hline Location & Zwierzyniec & Młyny & Pasturka 1a & Pasturka 1b & Pasturka 1c & Pasturka 1d & Pasturka 1e & \\
\hline Date & 05.07 .06 & 05.07 .06 & 25.06 .07 & 25.06 .07 & 25.06 .07 & 15.07 .08 & 15.07 .08 & \\
\hline Area of relevé $\left(\mathrm{m}_{\imath}\right)$ & 100 & 90 & 100 & 100 & 100 & 100 & 100 & $\mathrm{C}$ \\
\hline Exposure & $\mathrm{E}$ & SSE & $S$ & $\mathrm{~S}$ & $\mathrm{~S}$ & $S$ & $\mathrm{~S}$ & $\mathrm{o}$ \\
\hline Inclination & $<1$ & 20 & 5 & 3 & 3 & 3 & 15 & $\mathrm{n}$ \\
\hline Latitude $[\mathrm{N}]$ & $50^{\circ} 31^{\prime} 02,2{ }^{\prime \prime}$ & $50^{\circ} 32^{\prime} 46,3 \prime$ & $50^{\circ} 30^{\prime} 32,56^{\prime \prime}$ & $50^{\circ} 30^{\prime} 31^{\prime \prime}$ & $50^{\circ} 30^{\prime} 33^{\prime \prime}$ & $50^{\circ} 30^{\prime} 27,31^{\prime \prime}$ & $50^{\circ} 30^{\prime} 24,7^{\prime \prime}$ & $\mathrm{s}$ \\
\hline Longitude [E] & $20^{\circ} 42^{\prime} 35,3^{\prime \prime}$ & $20^{\circ} 44^{\prime} 01,5^{\prime \prime}$ & $20^{\circ} 33^{\prime} 41,69^{\prime \prime}$ & $20^{\circ} 33^{\prime} 47^{\prime \prime}$ & $20^{\circ} 33^{\prime} 44^{\prime \prime}$ & $20^{\circ} 33^{\prime} 42,85^{\prime \prime}$ & $20^{\circ} 34^{\prime} 07,5^{\prime \prime}$ & $\mathrm{t}$ \\
\hline Altitude (m) & 192 & 230 & 220 & 223 & 227 & 208 & 232 & $\mathrm{a}$ \\
\hline Density of tree layer A (\%) & 0 & 0 & 0 & 0 & 0 & 0 & 10 & $\mathrm{n}$ \\
\hline Density of shrub layer B (\%) & 20 & 0 & 0 & 0 & 0 & 0 & 20 & $\mathrm{c}$ \\
\hline Density of herb layer C (\%) & 60 & 70 & 80 & 80 & 90 & 75 & 75 & $\mathrm{y}$ \\
\hline Density of moss layer D (\%) & 10 & 20 & 0 & 0 & 0 & 0 & $<1$ & \\
\hline Number of species & 60 & 46 & 33 & 44 & 56 & 36 & 58 & \\
\hline $\begin{array}{l}\text { Orobanche arenaria } \\
\text { Ch. Festuco-Brometea }\end{array}$ & 1 & + & 1 & + & + & + & + & $\mathbf{V}$ \\
\hline Artemisia campestris & 3 & 2 & 4 & 3 & 2 & 3 & 3 & V \\
\hline Veronica spicata & . & + & + & + & + & + & + & $\mathrm{V}$ \\
\hline Centaurea stoebe & + & + & . & . & + & + & + & IV \\
\hline Achillea pannonica & + & + & + & + & . & . & . & III \\
\hline Campanula sibirica & 1 & 1 & . & . & . & . & 1 & III \\
\hline Euphorbia cyparissias & . & + & . & . & + & . & + & III \\
\hline Potentilla arenaria & + & 1 & . & . & . & . & + & III \\
\hline Alyssum montanum & . & 1 & . & . & . & . & + & II \\
\hline Acinos arvensis & 1 & . & . & . & . & . & + & II \\
\hline Centaurea scabiosa & + & + & . & . & . & . & + & II \\
\hline Linum hirsutum & . & . & . & . & + & . & + & II \\
\hline Phleum phleoides & . & . & + & . & + & . & . & II \\
\hline \multicolumn{9}{|c|}{ Ch. Koelerio glaucae-Corynephoretea canescentis } \\
\hline Silene otites & + & + & + & + & 1 & . & . & IV \\
\hline Trifolium arvense & . & . & 2 & 3 & 4 & 3 & + & IV \\
\hline Sedum acre & 1 & + & . & . & + & . & + & III \\
\hline Androsace septentrionalis & + & + & . & . & + & . & . & III \\
\hline Chondrilla juncea & . & . & + & + & . & + & . & III \\
\hline Helichrysum arenarium & + & . & . & . & . & + & . & II \\
\hline Plantago arenaria & . & . & . & + & 1 & . & . & II \\
\hline Thymus serpyllum & . & 1 & . & . & . & . & + & II \\
\hline \multicolumn{9}{|c|}{ Ch. Agropyretea intermedio-repentis } \\
\hline Elymus repens & . & + & 2 & 3 & 2 & 4 & + & V \\
\hline Anthemis tinctoria & + & + & . & . & + & + & + & IV \\
\hline Convolvulus arvensis & . & + & + & + & . & + & & III \\
\hline Elymus hispidus subsp. hispidus & . & . & . & . & . & + & + & II \\
\hline Falcaria vulgaris & . & . & . & . & . & 1 & + & II \\
\hline \multicolumn{9}{|l|}{ Ch. Molinio-Arrhenatheretea } \\
\hline Daucus carota & + & + & . & . & + & . & + & III \\
\hline Festuca rubra s. 1. & + & . & . & + & + & 2 & 1 & III \\
\hline Plantago lanceolata & . & + & + & . & . & . & + & III \\
\hline Rumex acetosa & + & . & + & + & . & + & . & III \\
\hline Taraxacum officinale s. 1. & + & . & + & . & + & . & . & III \\
\hline Achillea millefolium & . & + & . & . & . & . & + & II \\
\hline Arrhenatherum elatius & 1 & . & . & . & . & . & 3 & II \\
\hline Dactylis glomerata & . & . & . & + & . & + & . & II \\
\hline Holcus lanatus & . & . & + & + & . & . & . & II \\
\hline Lolium perenne & . & . & . & 1 & 2 & . & . & II \\
\hline Vicia cracca & . & . & + & . & . & + & . & II \\
\hline \multicolumn{9}{|l|}{ Ch. Artemisietea vulgaris } \\
\hline Echium vulgare & + & 1 & 1 & + & + & + & + & V \\
\hline Berteroa incana & + & . & 1 & + & + & + & . & IV \\
\hline Melandrium album & + & . & + & + & + & + & . & IV \\
\hline Oenothera biennis & + & + & . & . & . & + & + & III \\
\hline Picris hieracioides & + & + & . & . & + & + & . & III \\
\hline Anchusa officinalis & . & . & . & + & + & + & . & III \\
\hline Linaria vulgaris & . & . & + & 1 & + & . & . & III \\
\hline Tragopogon dubius & + & . & + & . & + & . & . & III \\
\hline Artemisia vulgaris & . & . & + & . & + & . & . & II \\
\hline Melilotus officinalis & . & . & . & + & . & . & + & II \\
\hline \multicolumn{9}{|l|}{ Ch. Stellarietea mediae } \\
\hline Conyza canadensis & + & . & 1 & + & + & + & . & IV \\
\hline
\end{tabular}


TABLE 1. Cont.

\begin{tabular}{|c|c|c|c|c|c|c|c|c|}
\hline & 1 & 2 & 3 & 4 & 5 & 6 & 7 & \\
\hline Papaver rhoeas & + & + & . & + & + & + & . & IV \\
\hline Apera spica-venti & + & . & + & . & + & + & . & III \\
\hline Lathyrus tuberosus & + & . & . & + & + & . & + & III \\
\hline Consolida regalis & + & . & . & + & . & + & . & III \\
\hline Descurainia sophia & . & . & . & + & + & . & . & II \\
\hline Fallopia convolvulus & . & . & + & . & + & . & . & II \\
\hline Myosotis arvensis & + & . & . & . & . & + & . & II \\
\hline Raphanus raphanistrum & . & . & . & + & + & . & . & II \\
\hline Vicia angustifolia & + & . & . & . & . & . & + & II \\
\hline Vicia hirsuta & . & . & . & . & + & + & . & II \\
\hline Viola arvensis & . & . & . & + & + & . & . & II \\
\hline \multicolumn{9}{|c|}{ Ch. Trifolio-Geranietea sanguinei } \\
\hline Medicago falcata & + & 1 & + & + & . & + & 2 & $\mathrm{~V}$ \\
\hline Coronilla varia & 1 & + & + & . & + & . & + & IV \\
\hline Origanum vulgare & . & . & . & + & + & + & + & III \\
\hline Verbascum lychnitis & . & 1 & + & 1 & 1 & . & . & III \\
\hline Galium verum & . & + & . & . & . & . & 1 & II \\
\hline \multicolumn{9}{|l|}{ Others } \\
\hline Senecio jacobaea & 1 & + & . & + & + & + & + & $\mathrm{V}$ \\
\hline Hypericum perforatum & . & + & + & + & . & + & + & IV \\
\hline Erigeron acer & + & + & . & 1 & + & . & + & IV \\
\hline Medicago lupulina & + & . & . & 1 & + & + & + & IV \\
\hline Arenaria serpyllifolia & 1 & . & 2 & 2 & 2 & . & . & III \\
\hline Hieracium pilosella & 1 & 3 & . & + & . & . & . & III \\
\hline Holosteum umbellatum & + & + & . & . & . & . & + & III \\
\hline Medicago sativa & . & . & 2 & 1 & + & . & . & III \\
\hline Pimpinella saxifraga & + & + & . & . & . & . & + & III \\
\hline Sedum maximum & . & . & . & . & + & + & + & III \\
\hline Veronica arvensis & + & + & . & . & + & . & . & III \\
\hline Calamagrostis epigejos & + & . & . & . & . & . & + & II \\
\hline Euphorbia esula & . & . & + & + & . & . & . & II \\
\hline Festuca trachyphylla & + & + & . & . & . & . & . & II \\
\hline Medicago minima & . & . & . & + & 1 & . & . & II \\
\hline Orobanche coerulescens & . & . & . & + & + & . & . & II \\
\hline Pinus sylvestris B & 2 & . & . & . & . & . & 2 & II \\
\hline Silene vulgaris & + & . & . & . & . & . & + & II \\
\hline Verbascum densiflorum & + & . & . & . & . & + & . & II \\
\hline
\end{tabular}

Sporadic: Ch. Festuco-Brometea: Allium oleraceum 7; Asparagus officinalis 5; Asperula cynanchica 7; Brachypodium pinnatum 7; Campanula bononiensis 7; Carlina vulgaris 1; Dianthus carthusianorum 5; Eryngium campestre 1; Helianthemum nummularium 2; Koeleria macrantha 2. Ch. Molinio-Arrhenatheretea: Agrostis gigantea 1; Anthyllis vulneraria 2; Galium mollugo s. 1. 7; Knautia arvensis 5; Pastinaca sativa 5; Tragopogon pratensis 1; Trifolium pratense 3. Ch. Artemisietea vulgaris: Carduus acanthoides 4; C. crispus 1; Melilotus albus 2. Ch. Stellarietea mediae: Anagallis foemina 7(r); Arabidopsis thaliana 2; Bupleurum rotundifolium 7(r); Ceratodon purpureus D 1; Equisetum arvense 6; Euphorbia exigua 7(r); Geranium pusillum 1; Lactuca serriola 1; Matricaria maritima subsp. inodora 5; Melandrium noctiflorum 4; Vicia tetrasperma 5. Others: Ajuga chamaepitys 7(r); Alyssum alyssoides 1(1); Bromus tectorum 5; Bryum sp. D 1; Camelina microcarpa subsp. sylvestris 1; Cardaminopsis arenosa 2; Erigeron annuus 7; Euphrasia stricta 2; Fragaria vesca 7; Hypnum cupressiforme D 1(1); Lappula squarrosa 5; Lavathera thuringiaca 3; Ononis arvensis 7; Orobanche elatior 7; O. picridis 5; Pinus sylvestris A 7(1); Poa compressa 2; Prunus spinosa C 7; Pycnothelia papillaria D 2; Robinia pseudoacacia B 1; Rubus caesius 6; Senecio sylvaticus 1; S. vernalis 4; Thalictrum minus 7; Thuidium sp. D 2; Veronica verna 5; Vincetoxicum hirundinaria 7.

and the Pasturka village; ATPOL: EF1420 (Fig. 2). The Garb Pińczowski ridge is formed by chalky rocks, covered with loose and strongly limy sands in some places near the base. The distribution of the species is quite dispersed. It consists of three subpopulations scattered over 7,5 ha.

The first subpopulation is located in lower parts of the southern slope and at its foot (Fig. 2). The species grows in fallows and in loose xerothermic grasslands on sands. It neighbours with grasslands and xerothermic shrublands to the north (Festuco-Brometea, Trifolio-Geranietea, Rhamno-Prunetea classes) and with cultivated fields to the south. Approximately 600 specimens were recorded at the locality in 2007. In 2008 the population decreased after intensive ploughing of the fallows. It is very likely that the ploughing caused irregular blossoming of the species: about $70 \%$ specimens flowered two weeks later than the rest of the subpopulation. Species characteristic of the Festuco-
Brometea class dominate in vegetation patches located in lower parts of the hill (Table 1 no. 3; Fig. 3) with a more numerous share of species characteristic of Artemisietea vulgaris, Koelerio glaucae-Corynephoretea canescentis, Agropyretea intermedio-repentis. On the other hand, species characteristic of the Koelerio glaucae-Corynephoretea canescentis class dominate in the undergrowth, with a substantial share of species characteristic of the Festuco-Brometea class and Agropyretea intermedio-repentis, MolinioArrhenatheretea, Artemisietea vulgaris, in vegetation patches located lower, in deeper sands (Table 1 no. 4 and 5; Fig. 3).

The second subpopulation is located about $150 \mathrm{~m} \mathrm{SE}$ of the previous one towards an asphalt road from Pińczów to Busko-Zdrój (Fig. 2) in an old fallow between cultivated fields. It consists of approximately 400 specimens. Species of the Agropyretea intermedio-repentis class dominate in 


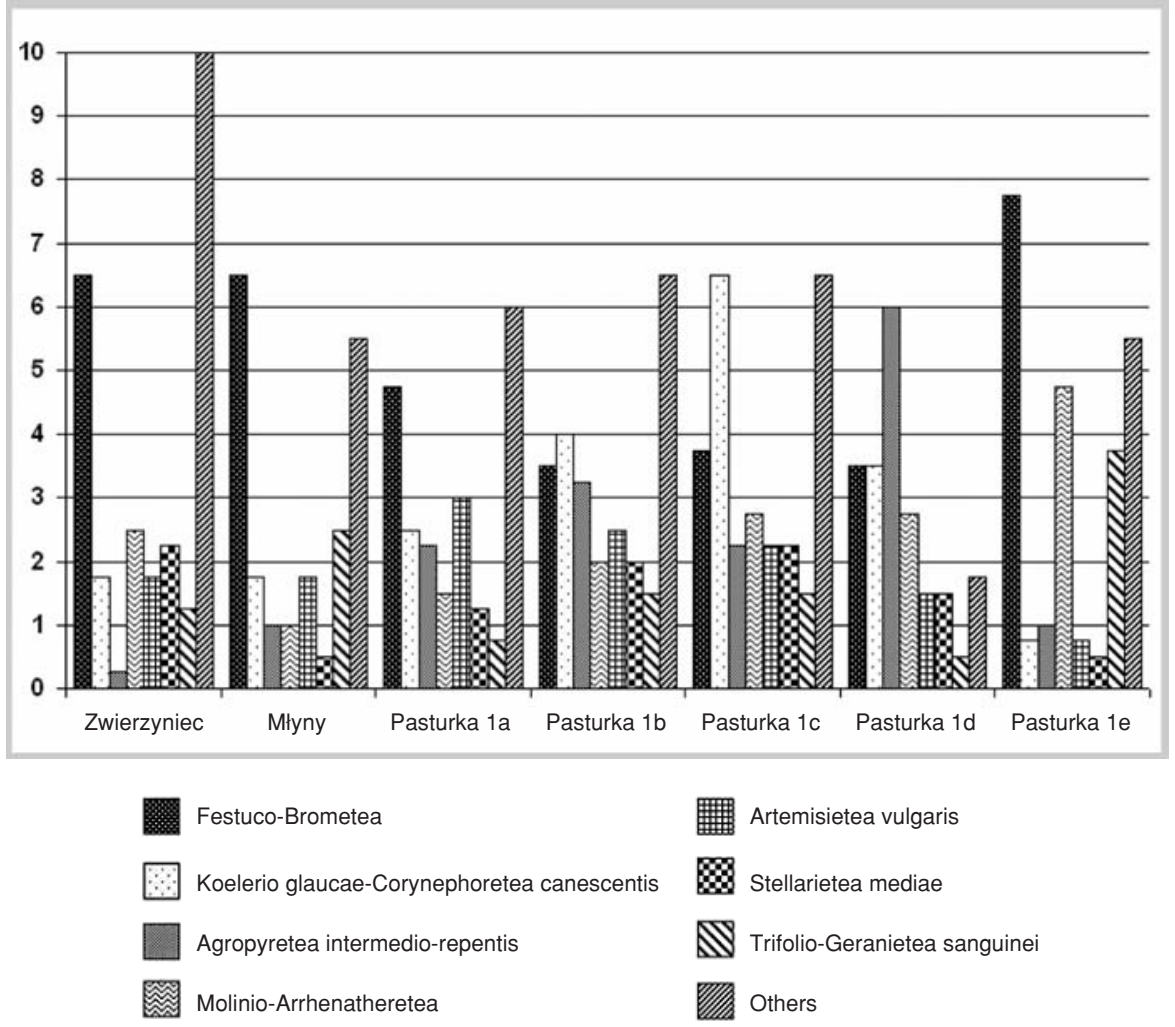

Fig. 3. The presence of species characteristic of individual phytocoenoses at the localities of Orobanche arenaria Borkh. vegetation patches and are associated with species of the Festuco-Brometea and Koelerio glaucae-Corynephoretea canescentis classes (Table 1, no. 6; Fig. 3).

The third subpopulation was discovered on the border between a pine forest and a fallow. It is located about $1 \mathrm{~km}$ $\mathrm{N}$ of the Pasturka village and about $1 \mathrm{~km} \mathrm{E}$ and $\mathrm{NE}$ of the neighbouring localities (Fig. 2). Orobanche arenaria grows on the slope of a $15^{\circ}$-incline hill with an SSE exposure. The grassland is formed on sands over the habitat of an old fallow sparsely overgrown with young pines developed from self-sowing. It borders on xerothermic grasslands to the north, fields to the west and south and a pine forest (known as the "Pasturski Forest") to the east. Approximately 30 specimens were recorded in 2008. Four layers are recorded in the vegetation structure (Table 1 no. 7). Pine occurs in the tree stand with a low crown closure and in the undergrowth. The herb layer is dominated by species characteristic of the Festuco-Brometea class and, further, by: Molinio-Arrhenatheretea, Trifolio-Geranietea sanguinei and Koelerio glaucae-Corynephoretea canescentis (Fig. 3).

A total of ca. 1030 specimens were recorded at the locality near Pasturka.

Locality II. Situated in the eastern part of Młyny, between Młyny and the Busko-Zdrój - Kielce road; ATPOL: EF1501 (Fig. 2). The species grows in a xerothermic grassland developed on very fertile calcareous sands, on the slope of a river valley (the Bród river). The area has a considerable incline $\left(20^{\circ}\right)$ with a S and SW exposure. The slope borders on the river valley to the south and the east and on cultivated fields (mainly cereal crops) to the north. Approximately 40 specimens were recorded. The community with Orobanche arenaria is dominated by species of the Festuco-Brometea class and much less by the Trifolio-Ge- ranietea sanguinei or Koelerio glaucae-Corynephoretea canescentis classes (Table 1 no. 2; Fig. 3).

Locality III. Discovered N of Zwierzyniec, near Szaniec, by an asphalt road from Szaniec to the Busko-Zdrój Chmielnik road, near a gravel pit; ATPOL: EF1510 (Fig. 2). Orobanche arenaria grows on sandy fallows sparsely overgrown with Pinus sylvestris. It borders on the BuskoZdrój - Chmielnik road to the north, cultivated fields to the west and the south, and a gravel pit and a pine forest to the east. Approximately 350 specimens were recorded. The species composition of the grassland is similar to that in Młyny. A slightly higher share of species of the FestucoBrometea, Molinio-Arrhenatheretea and the Stellarietea mediae classes is observed here (Table 1 no. 1; Fig. 3).

\section{CONCLUSIONS}

Orobanche arenaria parasitized only Artemisia campestris at the localities. The altitudinal range of the populations was between 190 and ca. $240 \mathrm{~m}$. The species was mostly observed as a single specimen or sometimes as clusters consisting of three to ten specimens (especially at locality near Zwierzyniec) in sites immediately adjacent to the previous year's specimens.

At the new localities, the species prefers dry, loose sandy and gravelled substrates with a high calcium carbonate content, often with calcareous stones. It occupies slopes with a different degree of incline $\left(3^{\circ}-20^{\circ}\right)$, with a southern exposure, or sporadically flat areas. The places are light, well insolated, exceptionally with some mosaic shading from trees, and usually comprise extensively used fields: fallows, pastures, slopes of river valleys as well as secon- 
dary habitats such as sand pits and gravel pits. The areas must have been cultivated intensively in the past as the soil horizon shows an arable level.

Specific combinations of thermophilic xerothermic grasslands and grasslands on sands are typical plant formations in which Orobanche arenaria occurs. Species of the Festuco-Brometea class and the Cirsio-Brachypodion pinnati association (Table 1 no. 1-3 and 7; Fig. 3), or interchangeably species of the Koelerio glaucae-Corynephoretea canescentis class and the Koelerion glaucae association (Table 1 no. 4 and 5; Fig. 3) dominate in the species composition of the communities. Species of the Agropyretea intermedio-repentis class dominated at one locality (Table 1 no. 6 , Fig. 3). Main syntaxonomic groups are frequently associated with Molinio-Arrhenatheretea grassland species, Artemisietea vulgaris ruderal species and Stellarietea mediae segetal species (Fig. 3). This species composition both shows the history of the habitats and is a result of the close proximity to cultivated fields, roads and xerothermic grasslands. However, O. arenaria does not enter fields or, importantly, dense xerothermic grasslands. The latter are more stable and denser, and $O$. arenaria loses competition with typical steppe species. An unambiguous classification of phytocoenoses in the area into specific associations defined in the literature cannot be performed.

\section{THREATS AND PROTECTION METHODS}

Threat symptoms are evident at the new localities. The population of Orobanche arenaria at the locality in Młyny is not numerous (40 specimens). The slope, on which the species grows, borders on cultivated fields from which chemical substances flow. As tree and shrub plantations with pines and black locusts grow on the adjacent slopes, the locality is threatened by secondary succession processes.

The locality near Zwierzyniec seems to be under particular threat as it is near an expanding gravel pit. Partial damage of specimens by lorries transporting gravel was observed in 2008. The locality is near an asphalt road, cultivated fields and, especially, a pine forest. Young pine specimens are recorded at the locality and the site is not likely to survive unless active protection is introduced.

The locality in Pasturka is threatened by herbicides, which was observed in 2008. As extensive cultivation is abandoned, and especially as occasional soil scarification is discontinued, the abundance of the field layer increases, which is unfavourable for Orobanche arenaria. The type of dissemination is anemohydrochoric (Teryokhin and Kravtsova 1986) and seeds can better penetrate the soil with water after soil treatment has been performed. In 2008 the fallow at the locality in Pasturka was ploughed and alfalfa was sowed. It initially seemed that the locality would be destroyed as the species did not appear in the flowering period or it appeared very weakly and not in large numbers. However, its mass occurrence was observed after approximately a two-week delay. One of the localities in Pasturka is partly situated in the direct vicinity of a pine forest which is a source of pine sowing onto the area with $O$. arenaria triggering off processes of secondary succession.

The locality of Orobanche arenaria in Glinany near Lubiąż (Lower Silesia) is also threatened by processes of se- condary succession and the adjacent pit can be filled up or can undergo eutrophication (Szczęśniak 2003).

The new localities of Orobanche arenaria are some of the most numerous localities in Poland and in central Europe. Importantly, they are located on the northern limit of the range. Although they are situated in the Nida Landscape Park and the Szaniec Landscape Park, the localities should additionally be included in an environmental monitoring programme and should be protected as ecological sites. Active protection measures such as periodical removal of excessively regenerating trees and bushes and inhibiting the development of an expanding herb layer should be introduced. Periodic and controlled soil scarification is also recommended.

\section{ACKNOWLEDGEMENTS}

The authors thank Ewa Szczęśniak and Zygmunt Dajdok for their help in situating the localities and for providing access to unpublished data on the species in Lower Silesia, and Prof. Adam Zając for his helpful comments improving the manuscript.

This work was supported by the Ministry of Science and Higher Education (grant no. 3577/B/P01/2007/33).

\section{LITERATURE CITED}

BECK VON MANNAGETTA G.R. 1890. Monographie der Gattung Orobanche. Biblioth. Bot. 19; Cassel.

BECK VON MANNAGETTA G.R. 1930. Orobanchaceae L. In: A. Engler (eds), Das Pflanzenreich IV. (261); Leipzig.

CHATER A.O., WEBB D.A. 1972. Orobanche L. In: T.G. Tutin, V.H. Heywood, N.A. Burges, D.M. Moore, D.H. Valentine, S.M. Walters, D.A. Webb, Flora Europaea 3: 286-293. Cambrige.

ELLENBERG H. 1979. Zeigerwerte der Gefässpflanzen Mitteleuropas. 2 Aufl. Scripta Geobot. 9: 1-122.

FABISZEWSKI J., KWIATKOWSKI P. 2002. Threatened vascular plants of the Sudeten Mountains. Acta Soc. Bot. Pol. 71(4): 339-350.

FOLEY M.J.Y. 2001. Orobanche. In: S. Castroviejo (eds), Flora Iberica. Plantas vasculares de la Península Ibérica e Islas Baleares. XIV. Real Jardín Botánico, CSIC. Madrid.

GILLI A. 1966a. Orobanchaceae. In: G. Hegi (ed.), Illustrierte Flora von Mitteleuropa 6 (1): 470-505. München.

GILLI A. 1966b. Bestimmungsschlüssel der mitteleuropäischen Varietäten und Formen von Orobanche. Verh. Zool.-Bot. Ges. in Wien. 105/106: 171-181. Wien.

HALAMSKI A.T. 2005. Orobanche lucorum zawleczona do Ogrodu Botanicznego UW. Biuletyn Ogrodów Botanicznych 14: 115-117. (in Polish with English summary)

HOLUB J. 1977. New Names in Phanerogamae 6. Folia Geobot. Phytotax. 12: 417-432, Praha.

HOLUB J. 1990. Some taxonomic and nomenclature changes within Orobanche s.1. (Orobanchaceae). Preslia 62: 193-198.

HOLUB J., ZÁZVORKA J. 1999. Phelipanche arenaria (Borkh.) Pomel. In: J. Čeřovský, V. Feráková, J. Holub, S. Maglocký, F. Procházka (eds), Červená kniha ohrozených a vzácných druhov rastlin a živočichov SR a ČR. 5. Vyššie rastliny. Priroda a. s., Bratislava. (in Slovak)

KĄCKI Z., DAJDOK Z., SZCZĘŚNIAK E. 2003. Czerwona lista roślin naczyniowych Dolnego Śląska. In: Z. Kącki (eds), Zagrożone gatunki flory naczyniowej Dolnego Śląska. pp.: 9-65. Instytut Biologii Roślin, Uniwersytet Wrocławski, Polskie Towarzystwo Przyjaciół Przyrody "Pro Natura”, Wrocław. (in Polish) 
KNAPP J.A. 1872. Die bisher bekannten Pflanzen Galiziens und der Bukowina. W. Braumüller Verl., Wien.

KREUTZ C.A.J. 1995. Orobanche. The European broomrape species. Central and northern Europe. Limburg.

MĄDALSKI J. 1967. Orobanchaceae. In: K. Browicz et al. (ed.), Flora Polska. Tom XI, 25-53; Warszawa, Kraków. (in Polish)

MEUSEL H., JÄGER E., RAUSCHERT S., WEINERT E. 1978. Vergleichende chorologie der Zentraleuropäischen flora. Bd II. G. Fischer Verl. Jena.

MULLER W. 1911. Flora von Pommern. 3 Aufl. Burmeister's Buchhandlung, Stettin.

NOVOPKROVSKIJ I.V., TZVELEV N.N. 1958. Zarazichovye Orobanchaceae Lindl. In: V.L. Komarov (ed.), Flora SSSR 23: 19-117. Moskwa-Leningrad.

OBERDORFER E. 1994. Pflanzensoziologische Exkursionsflora. Verl. E. Ulmer, Stuttgart, p. 1014.

PIGNATTI S. 1982. Flora d'Italia, Orobanchaceae: 606-616. Bologna. (in Italian)

PUJADAS-SALVÁ A., HERNÁNDEZ-BERMEJO E., OLIVEIRA-VELLOSO J.A.R. 1994. The genus Orobanche in Andalusia (southern Spain); taxonomical, chorological and ecological aspects. In: A.H. Pieterse, J.A.C. Verkleij, S.J. ter Borg (eds), Biology and management of Orobanche, Proceedings of the Third International Workshop on Orobanche and related Striga research. Amsterdam, The Netherlands, Royal Tropical Institute, 1994.

PUSCH J., BARTHEL K.J. 1992. Über Merkmale und Verbreitung der Gattung Orobanche L. in den östlichen Bundesländern Deutschland. Gleditschia 20 (1): 35-56. Berlin.

ROTHMALER W., JÄGER E.J., WERNER K. 2002. Exkursionsflora von Deutschland - Kritischer Band 4. Berlin.

RUTKOWSKI L. 1997. Rośliny naczyniowe - Tracheophyta. In: J. Buszko, K. Kasprzyk, T. Pawlikowski, A. Przystański, L. Rutkowski (eds), Czerwona lista roślin i zwierząt ginących i zagrożonych w regionie kujawsko-pomorskim. Acta Univ. Nicolai Copernici. Biologia LIII, Suplement-Nauki Mat.Przyr. 98. Toruń. (in Polish)

RUTKOWSKI L. 2004. Klucz do oznaczania roślin naczyniowych Polski niżowej. Wydawnictwo Naukowe PWN, Warszawa. (in Polish)

SCHNEEWEISS G.M., COLWELL A., PARK J.M., JANG C.G., STUESSY T.F. 2004a. Phylogeny of holoparasitic Orobanche (Orobanchaceae) inferred from nuclear ITS-sequences. Molecular Phylogenetics and Evolution 30: 465-478.

SCHNEEWEISS G.M., PALOMEQUE T., COLWELL A.E., WEISS-SCHNEEWEISS H. 2004b. Chromosome numbers and karyotype evolution in holoparasitic Orobanche (Orobanchaceae) and related genera. Am. J. Bot. 91: 439-448.

SCHUBE T. 1903. Die Verbreitung der Gefäßpflanzen in Schlesien preußischen und österreichischen Anteils. Druck von R. Nischowsky, Breslau.
SCHUBE T. 1926. Die Ergebnisse der Durchforschung der schlesischen Gefässpflanzenwelt im Jahre 1925. Jber. Schles. Ges. Vaterl. Cultur 98: 9-15.

SOJÁK J. 1972. Nomenklatorické poznámky (Phanerogamae). Časopis Národniho Muzea, odd. přrodovêdnỳ 140: 127-134. (in Czech).

SZCZEŚNIAK E. 2003. Rzadkie i zagrożone gatunki ciepłolubnych muraw na Dolnym Śląsku. In: Z. Kącki (eds), Zagrożone gatunki flory naczyniowej Dolnego Śląska. pp.: 85-107. Instytut Biologii Roślin, Uniwersytet Wrocławski, Polskie Towarzystwo Przyjaciół Przyrody "Pro Natura", Wrocław. (in Polish)

TERYOKHIN E.S., KRAVTSOVA T.I. 1986. The development and the structure of the seed coat in some representatives of the Orobanchaceae of the flora USSR. Bot. J. 71: 1501-1512.

TERYOKHIN E.S., SHIBAKINA G.V., SERAFIMOVICH N.B., KRAVTSOVA T.I. 1993. Opieredelitelj Sarasichovich Florii SSSR. Nauka. St. Petersburg, Russia. (with English summary)

TZVELEV N.N. 1981. Orobanchaceae. In: A.A. Fedorov (ed.), Flora evropeyskoy chastii SSSR 5: 317-335. Izdatel'stvo Nauka, Leningrad.

UHLICH H., PUSCH J., BARTHEL K.J. 1995. Die Sommerwurzarten Europa: Gattung Orobanche. Westarp-Wiss., Magdeburg.

ZAJĄC A. 1978. Założenia metodyczne "Atlasu rozmieszczenia roślin naczyniowych w Polsce”. Wiad. Bot. 22(3): 145-155. (in Polish)

ZAJAC A., ZAJAC M. (eds). 2001. Atlas rozmieszczenia roślin naczyniowych w Polsce. Pracownia Chorologii Komputerowej Instytutu Botaniki Uniwersytetu Jagiellońskiego, Kraków. (in Polish)

ZARZYCKI K., SZELĄG Z. 2006. Red list of the vascular plants in Poland. In: Z. Mirek, K. Zarzycki, W. Wojewoda, Z. Szeląg (eds), Red list of plants and fungi in Poland. pp.: 9-20. W. Szafer Institute of Botany, Polish Academy of Sciences, Kraków.

ZARZYCKI K., TRZCIŃSKA-TACIK H., RÓŻAŃSKI W., SZELĄG Z., WOŁEK J., KORZENIAK U. 2002. Ecological indicator values of vascular plants of Poland. W. Szafer Institute of Botany, Polish Academy of Sciences. Kraków.

ZÁZVORKA J. 2000. Orobanchaceae - zarazovite. In: B. Slavik (ed.), Kvetena Česke Republiky 6. Academia Praha. (in Czech).

ŻUKOWSKI W., JACKOWIAK B. 1995. List of endangered and threatened vascular plants in Western Pomerania and Wielkopolska (Great Poland). In: W. Żukowski, B. Jackowiak (eds), Endangered and threatened vascular plants of Western Pomerania and Wielkopolska. Publications of the Departament of Plant Taxonomy of Adam Mickiewicz University in Poznań 3. Poznań 